\title{
CAN SEQUENTIAL AND NON-DUALISTIC INTERPRETATION OF MARX'S MONETARY THOUGHT BE SYNTHESIZED WITH THE POST-KEYNESIAN ENDOGENOUS MONEY PARADIGM?
}

\author{
Simon Mouatt July 2010 \\ Senior Lecturer in Economics \\ Southampton Solent University \\ simon.mouatt@solent.ac.uk
}

\section{INTRODUCTION}

Yes, of course, why not? The temporal single system interpretation (TSSI) emerged in the early eighties, as a refutation of the simultaneous models adopted by many Marxists, which posited that Marx's schema needed to be interpreted sequentially (in the manner Marx intended) and that prices and values were inter-dependently determined (Kliman 2007). This work, in the main, has assumed the use of (real) commodity-money following Marx. ${ }^{1}$ Yet, can monies derived from credit be inserted in the models as appropriate monetary equivalents? This paper seeks to argue that they can, without any compromise of established TSSI principles. The endogenous money paradigm (EMP), as Naito notes, is generally accepted by many economists today and, this would therefore be an important step towards a modern Marxian monetary theory (Naito 2008). The paper further argues that, despite some ambiguities in his work, a more realistic (modern) conception of money can be derived from Marx. Much depends on the definitions used.

It is important to note that the TSSI understanding of Marx's monetary theory is fundamentally different to simultaneous interpretations, such as the models utilized in mainstream neo-classical approaches. Marshallian marginal analysis, for instance, makes use of static models to convey market information, that is assumed to be reflective of completed adjustments (Marshall 1890). Money is then added to the models and is presumed to have no impact on the equilibrium and price ratios established - a Walrasian price theory (Walras 1926; Harris 1981). Exogenous changes to the volume of money, in a Ricardian sense, increase the price level but are assumed to have no impact on relative prices. Is this realistic?

Firstly, when an exogenously-induced addition to the volume of money occurs (if this is possible) it is unlikely that it will be distributed proportionately across all commercial agents. Yet, it is this miraculous coincidence that is necessary in these neo-classical/Ricardian models. Secondly, as Potts notes, the capitalist economy is not a barter economy it is a monetary one. If the Walrasian notion assumes the (barter) exchange of products, in order to establish price ratios, then this is not an adequate explanation of the reality (Potts 2005). Thirdly, simultaneous models assume that production (and demand) conditions change, leading to a new equilibrium, rather than allowing for an (endogenous) price change to disturb the ratios. Yet, prices go up because people put them up, as commercial agents jostle

\footnotetext{
${ }^{1}$ Freeman, for instance, suggests that symbolic money has limited use outside of circulation in comparison to commodity money (that he uses in TSSI models of price, value and money stock) Potts, N. (2005). The Political Economy of Money, Profitability and Value. London School of Economics. London, University of London.
} 
for position. It is normal to expect that this is a continuous process in the real world, and one not (necessarily) determined by changes in the volume of money, and should therefore be taken into consideration by a model that purports to explain the operation of a monetary economy. Fourthly, money can be hoarded (and re-introduced from hoards), and agents can (whimsically) abstain from purchases, during the course of the circulation process. It is simply not appropriate, as Freeman noted, to assume Say's law in the social process of exchange (Freeman 1996). Fifthly, as the French/Italian circuitists have emphasised, monetary factors per se can have an instigative impact on new investment (and therefore equilibrium conditions) that would otherwise not happen (Graziani 2003). Money cannot just simply be ignored. Finally, it is assumed in simultaneous models that the money supply determines the price level. Yet, many (including some mainstream thinkers) have argued causality is the other way round. Marx adhered to this view where the overall price of goods (including money), in other words the price level, determines the value of (commodity) money and therefore the quantity required for circulation purposes (De Brunhoff 1976). ${ }^{2}$

Yet, is the neutrality of money confined to the neo-classical monetary model? Freeman explains how it is not possible to allow an operational role for money in all simultaneous models, including the models of the neo-classical (Keynesian) synthesis. Here the economy is separated into a real goods market, with output determined by simultaneous method and autonomous of monetary factors (except the interest rate), and a money market which is seen in isolation (Freeman 1996). These ideas found expression in the Hicks analysis of IS/LM curves. The IS curve is derived from a locus of points where the level of output is equilibrated with total spending, at a certain interest rate, and investment spending (with multiplier impact) rises at lower rates due to expected returns. The LM set of points, conversely, are derived from the (liquidity preference) 'demand for money' at varying government-fixed (exogenous) money supplies (Harris 1981). Yet, 'money matters' in the real world of markets, currencies and financial contracts and therefore needs to be considered as integrated with the real economy. Furthermore, it is simply not appropriate to consider an exogenous money supply with endogenous interest rates when, as the post-Keynesians have noted, the real world contains neither (Wray 2004). It might be that the denial of monetary factors by the mainstream economics profession, including the so-called 'Keynesians', is driven by the need to avoid the obligation of redesigning their economic models? Their ideas, prevalent since the late nineteenth century, appear to be inflexible and impervious to evident realities. As Freeman has noted regarding the economics discipline, 'the occasional and enforced recognition of reality by a Keynes or a Kalecki is quickly smothered and incorporated into what has become the most cynical of all occupations' (Freeman 1996).

\section{THE TEMPORAL SINGLE SYSTEM INTEPRETATION}

The TSSI method, conversely, begins by recognizing the essential social nature of money in exchange that also embodies the value of abstract labour - the real cost of production. It is not necessary however, as Potts notes in contradistinction to many Marxist economists, for the numeraire to be in a specific commodity-form since, this can be replaced by any monetary entity and the issuers of (the new) money then become 'goldmines' themselves (Potts 2005). This could, of course, include bank deposit monies that derive from the EMP

\footnotetext{
2 Potts notes that in booms, when goods are in short supply, prices rise relative to money and they therefore fall in a slump. These fluctuations happen (in contrast to the Ricardo view) regardless of what happens to the money supply. It is recognised, however (in line with Ricardo), that a paper issue will also raise prices Ibid.
} 
notion of money-creation where, bank decision-makers (and systemic factors) facilitate the money supply changes. The TSSI approach further assumes that money prices determine the exchange value of money and, as stated, the monetary unit itself embodies abstract social labour. Since the TSSI (unlike dual system interpretations) considers the reciprocal determining aspects of price and (labour) value, a common denominator is required to measure and compare their magnitudes. This is usually represented by the monetary expression of labour time (MELT), popularized by Ramos, which measures abstract labour in monetary terms at a point in time, since the exchange value of money is always in the process of change due to inflation (Ramos-Martinez 2004). However, the TSSI usually assumes a constant MELT for purposes of simplicity. Simultaneously, it is also recognized (following Marx) that random changes in the volume of money (utilized in circulation), through some transmission mechanism, will also precipitate price rises and, therefore, lower the value of money although, as De Brunhoff noted, Marx generally considered causality to run from prices to growth (in the circulating medium) rather than the reverse. These monies then, once issued, embody abstract labour and, as Marx noted, the holders of money then 'carry' these social relations on their persons (De Brunhoff 1976).

Notwithstanding, as Kliman notes, the TSSI does not claim Marx is necessarily the correct theoretical model to adopt overall, as a universal explanatory tool, but it does refute the myth of inconsistency that has surrounded his method. According to the TSSI, the 'law of value', and the falling rate of profit, both exert their pressure on the real economy and Marx's three fundamental equalities are shown to be consistent. These include the equality of aggregate profit and surplus value, aggregate value and aggregate prices of production and the equalized value and price rates of profit across the whole economy (Kliman 2007).

Kliman explains how Marx had distinguished between price and value in two different ways (Kliman 2007). On the one hand it is a manner of measurement of the commodity, which is sometimes measured in labour terms and sometimes in monetary terms. Marx also, on occasion, compares the two like, for example, when he was keen to illustrate the tendency of the 'law of value' to exert pressure on the 'enchanted' subjective world of market prices. In other parts of his text, Marx distinguishes between price and value when he wanted to differentiate between the value produced in production and, the value actually realized in monetary form. In order to illustrate this, and also the utility of the MELT where each hour of value created is given a nominal monetary measure, Kliman makes use of the following table where the MELT is $\$ 60$ per hour. The worker also works a 40 hour week and is paid $\$ 600$.

$\mathrm{c}_{\mathrm{VT}}=$ sum of value transferred

$\mathrm{v}=$ variable capital, value of the wage

$\mathrm{n}=$ new value created

$\mathrm{W}=$ value of output (value produced)

$\mathrm{p}=$ price of output (value received)

$\mathrm{s}=$ surplus value (surplus labour)

\begin{tabular}{|l|l|l|l|l|l|l|l|}
\hline & $\mathrm{c}_{\mathrm{VT}}$ & $\mathrm{v}$ & $\mathrm{n}$ & $\mathrm{w}=\mathrm{c}_{\mathrm{VT}}+\mathrm{n}$ & $\mathrm{p}$ & $\mathrm{s}=\mathrm{n}-\mathrm{v}$ & $\pi$ \\
\hline Dollars & 3600 & 600 & 2400 & 6000 & 5400 & 1800 & 1200 \\
\hline LabourHrs & 60 & 10 & 40 & 100 & 90 & 30 & 20 \\
\hline
\end{tabular}

Both of the distinctions that Marx made, between price and value, are evident in the table. It is also concluded that the firms realized output (price received) is $10 \%$ below its value, meaning that elsewhere in the system a firm(s) is realizing 10\% more (Kliman 2007). 
The TSSI, as mentioned above, states that prices and values reciprocally determine each other in a succession of periods of production and circulation. Prices determine the value magnitudes of production inputs and the general (labour value) rate of profit determines the tendential 'prices of production' (although realized prices normally differ) in circulation (Kliman 2007). In this conception it is the money actually spent on $\mathrm{C}+\mathrm{V}$ at the start of production that matters, and forms the representation of value (in labour terms) for purposes of further analysis. Conversely, virtually all of the modern Marxist interpretations suggest that value is transferred to new commodities from constant (means of production and raw materials) and variable capital, where the input value measured uses transformed (labour) values (at prices of production) so that these inputs equal outputs in a simultaneous equilibrium. This means that there are two separate 'cost prices' in this system, one that is based on monies actually spent and the other determined by the transformed (labour) inputs in money terms. Simultaneous Marxists argue that if the quantities differ in these systems the monies paid can be ignored since the 'real' prices of the inputs, at transformed prices that equal outputs, are the ones that are significant (Kliman 2007). There is, therefore, no attempt at all to create a model that reflects the reality. In these dualist interpretations, the prices of production are established first and then market prices may (and are expected to) revolve around them as axes. Yet, as Carchedi noted, in the real world the market prices are established first and then the prices of production (tendential prices) may gradually emerge, providing there are no counter-tendencies, over successive production periods (Carchedi 1996). Proponents of the TSSI, when abstracting to formulate models, posit (following Marx) that (subjectively-led) price formation (above or below 'prices of production') takes place during the production period that, in turn, determine the inputs of the (immediate) next production period. The post-production circulation, therefore, does not add any value in exchange or adjust the price ratios/level. The Carchedi/TSSI view thus presents Marx with a logical, realistic, and non-neutral, view of the role of money in successive production periods. In the TSSI, therefore, the central significance of money (in terms of real payments) has been reclaimed. Monetary factors in circulation (whilst formed during production) are no longer secondary and also, do determine real outcomes.

The classical economists had failed to resolve the conundrum of differing profit rates that were associated with varying organic compositions of capital. This was because they had previously posited that capitalist competition would tend to equalize profit rates, as capital migrates towards the highest returns. It was Marx's theoretical solution to this dilemma, that culminated in his transformation of values into 'prices of production', which has given rise to the historic claims of inconsistency known as the 'transformation problem'. Marx solves the problem by stating that total profit and total price, which are established in production, remain the same in aggregate whether prices have been adjusted to equalize profit or prices simply reflect their values (or neither). All this means that total profit and total price are just distributed differently during the random realm of circulation. Marx, quoted by Kliman, explains that "the ratio in which profit is divided, and the different legal titles by which this division takes place, already assume that profit is ready-made and pre-suppose its existence.....Profit is produced before this division takes place, and before there can be any talk of it" (Marx 1981). Kliman points out, however, that the profit may not be realised in the market but this is a separate matter to the establishment of profit in production. In addition, Kliman (following Marx) emphasizes that price (as well as value) is also established in production, prior to circulation, illustrating that exchange amounts to a 'zero-sum' game. If prices are realized in the market that deviate from their 'real' price then either seller or buyer gains at the expense of the other. The total amount of value established in production, 
remains the same (Kliman 2007). Kliman provides a simpler version of Marx's solution, without Marx's use of five branches of production and fixed capital (means of production that last beyond one production period), in order to illustrate his essential point.

\begin{tabular}{|l|l|l|l|l|l|l|l|l|}
\hline Branch & $c$ & $v$ & $\mathrm{~s}$ & $\mathrm{w}$ & $\pi$ & $p$ & $\mathrm{~s} /(\mathrm{c}+\mathrm{v})$ & $\pi /(c+v)$ \\
\hline 1 & 54 & 6 & 12 & 72 & 15 & 75 & $20 \%$ & $25 \%$ \\
\hline 2 & 16 & 4 & 8 & 28 & 5 & 25 & $40 \%$ & $25 \%$ \\
\hline Total & 70 & 10 & 20 & 100 & 20 & 100 & $25 \%$ & $25 \%$ \\
\hline
\end{tabular}

In the table $c, v$, and $s$ stand for constant capital, variable capital and surplus value, $w=$ $c+v+s$ is the value of the output, $\pi$ is average profit, and $p=c+v+\pi$ is the output's price of production. $s /(c+v)$ and $\pi /(c+v)$ are the value and price rates of profit. It is also not specified in the table whether the value and price sums are expressed in units of money or labour-time. In the table $c+v$ are data inputs that depend on the 'prices' paid, in keeping with the TSSI (and Marx), and derived magnitudes are the prices, profits and prices of profit. If the output at the end of the period was sold at value, there would not be an equalization of profit rates. Yet, when the prices of production are established $(p)$, then this becomes possible. Marx's solution, albeit subject to much criticism, also leads on to the successful and consistent (theoretical) establishment of his three aggregate equalities. In this simple model, it could be argued, that there is no prima facie impediment to the use of a credit-money unit as a monetary equivalent, in preference to a unit of commodity money.

\section{THE ENDOGENOUS MONEY PARADIGM}

In similarity to the TSSI, the post-Keynesian notion of money begins with an emphasis on its social features, which establishes the 'money of account' as an accepted convention which liberates the economy from the constraints of barter. In the modern era, following Hawtrey, bank deposits (created ex nihilo by lending) circulate as money (Hawtrey 1919). Credits and debits can be cleared through the use of the common unit, in the form of credit-money, affording a key role to the banks and the general demand for loans. Next, the post-Keynesians emphasise the nominality of the 'money of account', that is determined by the monetary authorities responsible for the jurisdiction. In line with the chartalist notion of money, following Knapp, the PK's further posit the accepted legitimacy of the monetary unit, derived from its acceptance by the state for the payment of taxes (Knapp 1924). This paper argues that this defined (credit) money-unit can then be utilized in the above mentioned TSSI model.

PK economics emerged in the seventies as a response to the post-war 'bastardisation' of Keynes (and the monetarist challenge), with its separate monetary and goods sectors, and aims to (re)establish Keynes as a monetary economist who was seeking to explore the (integrated) role of money in the productive economy (Tily 2006). In particular, PK theorists have sought to develop the notions of endogenous credit money, money (time) contracts and the role of uncertainty. The stated intention, in contradistinction to the mainstream, is to restore a measure of reality to economic analysis (Davidson 2002).

\section{WHAT DID MARX HAVE TO SAY ON THE MONEY ISSUE?}

Marx had recognized that in a monetary economy, where money is the only legitimate claim on wealth and is the only truly fungible entity, there is substantial social power wielded by 
those that control financial resources. This was particularly true of the state during the mercantilist era, when the nation-state focused on the accumulation of specie stocks in order to enhance its political aspirations. These ideas, as De Brunoff has noted, had been developed by Marx in the Critique of Political Economy but were not pursued further or discussed elsewhere (De Brunhoff 1976). Marx had perhaps wanted to focus on the material relations of production and the law of value, as drivers of human behavior, and leave the (full) discussion of the implications of financial power to the (more subjective) realm of political science?

Be that as it may, Marx had a particular view of money which began with an abstract discussion of the endogenous origin of money, money that is socially established as a monetary equivalent with intrinsic commodity value, through to the development of complex credit forms within the evolution of the capitalist mode of production (Marx 1976; Marx 1981). Surplus value is realised in the market in money-form and, simply represents abstract social labour. Money capital is transformed into the means of production (and labour-power) and then into commodities and finally back into money-form again - the metamorphosis of capital (Marx 1978). Capital accumulation also, of course, manifests in monetary nominal terms and money is the instigator of economic activity so is therefore indispensable to production. In essence, Marx's monetary ideas are simply extensions of his law of value and general political economy.

For Marx, the function of money follows from its nature as a commodity. In other words it is able to perform the functions of money because it is a commodity. In Marx's time this, of course, referred to gold - mined using human labour - that contained (dual) use-value (as money and precious metal) and hence an exchange value. There is an inference that in order to possess the social acceptability, that money requires, an entity needs to possess this commodity status. Yet, as Itoh notes (and argued here), it is irrelevant whether or not the commodity money has commodity value other than its use value as money and that, therefore, accounting prices could be set in value-less units of currency in an abstract sense (Itoh 1999). However, whilst Marx appreciated the existence of abstract money, that transfers (labour) value into price, and real money that transfers price in to a 'concrete equivalent' that contains the 'qualities of money' it has been generally assumed (perhaps erroneously) that Marx did not consider (or at least outline in his text) anything other than a commodity money containing such (final payment) qualities (Itoh 1999; Zarlenga 2002; Mouatt 2008). In the modern era, conversely, we have a complete fiat money and credit money system that is not specie backed and is fully legitimised by the modern state. Furthermore, following Knapp, since electronic bank monies are acceptable for the payment of taxes, they can be considered money proper (Knapp 1924). Marx in his textual analysis, however, had utilised gold (or specie backed paper) for illustrating payment settlement, although this does not preclude the a priori possibility of another (legally sanctioned) currency fulfilling the same purpose. Marx, had also recognised the unique capability of commodity money to transcend the boundaries of the nation-state, if the state ceased to exist for any reason (Marx 1970). Conversely, a 'means of account' currency, created and sanctioned by the authorities, is most likely to be unable to survive the demise of the state. For this reason, a counter interpretation of Marx's monetary theory is that he was unlikely to have been an uncompromising metallist (advocating specie-backing for currency as an imperative) but, rather, theorised monetary matters using specie because this represented the practical realities of his day (Mouatt 2008).

Furthermore, Marx had outlined the limitations of commodity money. In his Critique of Political Economy, for instance, Marx gives an illustration of a debate that had raged in the eighteenth century centred on the 'doctrine of the standard of money'(Marx 1970). The 
'standard of price' (the modern term) is the rate of exchange between the nominal value of currency and the commodity used for backing, which is arbitrarily set by the authorities. At the time of the accession of William of Orange (p.77) the mint-price of silver was $5 \mathrm{~s} 2 \mathrm{~d}$ (per $\mathrm{oz}$ ) but, its market price had risen to $6 \mathrm{~s} 3 \mathrm{~d}$. This was because clipping and abrasion (and possible dilution of the metal content) had reduced the silver content of coin. A study revealed that £57, 200 of coin weighed 141, 000 when it should have been 220,000 (Marx 1970). With commodity money there is always the practical difficulty (for monetary authorities) of relating the metal price to its nominal value (mint-price) to consider, where the market value may deviate from the one set, as well as deciding the correct quantity of minted coins in relation to circulating commodities. ${ }^{3}$ Those that recognised the former problem, such as Sir James Steuart, felt that those with money or tax obligations, due to creditors or the state, should be able to repay less coin as a result of any devaluation. This could be achieved by changing the mint-price to reflect the changes. However, at the time, dominant political figures like John Locke ensured this did not happen and this amounted to a de facto surplus for government and creditors (Marx 1970). The inequitable implications of which, Marx was no doubt fully aware. Marx anticipated, as Lapavitsas noted, that this debasement of the commodity money would prepare the way for more formal forms of state-issued symbolic money (Lapavitsas 1991). Be that as it may, for Marx, gold was money and its value was determined by the labour content that was embodied in it.

Marx had also discussed paper money created by the banking system, which he referred to as a 'money sign' (Mandel 1987). The paper money represents the money commodity nominally and can be exchanged for it. Marx had been sympathetic to the views of the banking school who felt that any excesses of paper money, above the necessary quantity of backing (not used for economic activity), would return to the banking system according to what is termed the 'law of the reflux' (Lapavitsas 1994; Itoh 1999). ${ }^{4}$ Marx emphasised these hoarding and paying functions of money, which tend to mitigate any inflationary impact of nominal money increases. If more money was needed to meet the circulation requirements, money could be drawn from hoards or the velocity of circulation could be increased. If less money was required, the law of the reflux would apply. In this sense the money (circulation) supply can be seen as partly endogenous and, non-neutral.

Marx had also considered the emerging bank activity of discounting bills of exchange, and overdraft facilities, which economised on the use of (real) money as a means of payment. ${ }^{5}$ In the modern era, the cheque clearing system, switch payments and direct debits use bank deposits in the same way. Modern economists all view bank deposits as (real) money but Marx (and most of his contemporaries) thought otherwise. Marx appeared only interested in that which fulfilled the functions of money (measure of value, means of exchange and world money) in the context of his time. In this sense, bank deposits per se did not fulfil the criteria. Yet, Marx did not seem to view these monies as particularly autonomous from the processes of industrial capital. He (as previously stated) had assumed that older forms of moneylending (pre-capitalist), in the form of financial capital, would be gradually replaced by such

\footnotetext{
${ }^{3}$ There are also the political problems of monopoly or cartel control of the supply of the given commodity.

${ }^{4}$ Lapavitsas argues that Marx had developed his monetary ideas more deeply than the Banking school by describing the different functions of commodity, fiat and credit monies Lapavitsas, C. (1994). "The Banking School and the Monetary Thought of Karl Marx." Cambridge Journal of Economics 18: 447-461.

${ }^{5}$ Marx also thought that the credit facilities enhanced the velocity of circulation Marx, K. (1970). $\underline{A}$
Contribution to the Critique of Political Economy. Union of Soviet Socialist Republics, Lawrence \& Wishart.
} 
bank provision to meet the evolving needs of industrial capital as the economic system developed (Marx 1971). He posited that as this occurred, monies lent as 'interest-bearing debt' became dependent on the expansion of value realised in the market, for continued existence, and monies advanced for purposes of circulation were secondary to it (Marx 1971).

Marx's general discussion of the credit system, is found in volume two and three of Capital (Marx 1978; Marx 1981). Marx initially presents money hoards, as reserve funds of latent money-capital, derived from the (previous) expansion of value from production. Marx had (Chap 17) argued that accumulation is the normal state of affairs for a capitalist economy, which takes place when part or all of the surplus value is advanced as new capital instead of being spent on consumption or the increase of hoards (Marx 1981). This accumulation then makes the increase of hoards possible, as surplus capital is directed towards them. Marx viewed (following Tooke) these hoards as regulators of monetary circulation, as they were withdrawn and released from use (Lapavitsas 1994). Marx had also recognised the social power of these hoards of monetary resources. for those that controlled them, and further recognised their (Chap 17) de facto claim on the annual produce (Marx 1978). In addition, Marx had posited that it was the capitalist ability to draw from these reserves that constituted a key defining feature separating the bourgeoisie from the proletariat (Marx 1848). Itoh explains how the existence of reserves then enabled capitalists to accept promissory notes, since the spare monies could be utilised to ensure the continuation of the production process during the time period before the debt settlement date (Itoh 1999).

Yet, despite the efficiency that credit affords to the capitalist mode of production, Marx's theoretical foundation for the operation of the system was the existence of idle funds $-100 \%$ fractionally backed lending. In the modern era, conversely (as the EMP recognises), money is created ex nihilo by the private banking infrastructure and does not require the pre-existence of funds prior to the lending contract (Hawtrey 1919; Naito 2008). In addition, even the necessary liquidity to meet capital adequacy requirements (legal and operational) does not have to pre-exist in order for lending to take place (Pettifor 2006; Rochon 2007). However, it could be argued that Marx's theoretical treatment of the credit system does not preclude the possibility of monies created in such a fashion, if money is defined in a certain way. Bills of exchange (and associated banknotes) that function as monies, for instance, could be conceived as contributing to the quantity of circulating currency (if the banknotes are defined as money) or (as Marx perhaps implied) simply economising on the use of (real) money that exists in the form of a commodity. If banknotes are money, then the monies could be conceived as being created ex nihilo, it all depends on definition. Yet, in contradistinction to the modern era, it was perhaps more rational for Marx (with the commodity money of his day) to make the separation between real and credit monies. Freeman (p.144) argued, for instance, that Marx abstracted from credit for purposes of concentrating on the 'essential nature of money in capitalist society' to improve explanatory clarity (Potts 2005).

An inhibitor to the advancement of monies as capital, from funds held in reserve, is the tendency for the rate of profit to fall (LTFRP). ${ }^{6}$ In these instances, capital can be tempted to migrate towards fictitious capital in the financial markets, induced by the prospects (for some) of greater returns. Yet, since the very existence of fictitious capital (nominal value in excess of the underlying abstract labour-time value) amounts to a zero-sum game, the activity can be precarious for agents and simply constitutes a (re)distribution of current nominal

\footnotetext{
${ }^{6}$ The TSSI reclaims the validity of Marx's ideas from the myth of inconsistency, in particular the tendency of the rate of profit (in labour terms) to fall as the organic concentration of capital increases.
} 
money (and hence social power) stocks. Those that gain, therefore, do so at the expense of others and no (surplus) value has been created in the process. In addition, the financial market conditions, associated with this capital migration, directly facilitate the creation of speculative asset 'bubbles' and the subsequent crises that follow. Stable expectations of asset appreciation, as Kregel notes, then contribute to the 'bubbles' as a result of rational behaviour (profit maximisation), rather than a psychological deficiency on behalf of the market participants (Kregel 2008). If greater margins were being achieved in the productive economy, circumstances would (arguably) be different. Marx had posited (Chap 30) that during an upturn in the trade cycle, there will be an expansion of credit (in terms of financial capital) and capital advanced from hoards, whilst the reduced expectations of capitalists during a downturn would lead to a contraction of credit and capital advanced (Marx 1981). It is in such financial crises, however, that Marx (and the TSSI) thought that (increased) demands for final payment in (real) money could only be satisfactorily provided by commodity money, as noted by Freeman quoting from Grundisse (Freeman 2004). Yet, in the current era, it could be argued that this is less important since bank (credit money) deposits constitute real money for the purposes of final payment settlement in a de facto sense.

There are three key areas where Marx's textual analysis of monetary matters would (arguably) benefit from greater theoretical development, in the context of modern monetary theory and the actual historical evolution of financial systems. Firstly, the theoretical use of commodity money needs to be modified since, in the modern era, money has no substantial intrinsic value (or backing) and exists almost exclusively in the form of digits on computer software. Secondly (and related), Marx did not include bank deposits as money, since he seemed only concerned with the actual monies (perhaps drawn from deposits) utilised in successive periods of production and circulation. ${ }^{7}$ Thirdly, Marx also did not provide a clear view of ex nihilo endogenous money-creation, despite his theorising of bills of exchange and overdraft facilities. In his general discussion of banking and the provision of financial capital, for instance, he presents the recycling of funds from surplus to deficit agents from a static stock rather than (as posited by PK's, circuitists and reformers) bank-monies derived from a balance-sheet accounting entry (Marx 1981). Yet, it is this PK view that is generally now accepted as the main method of money-creation and is the one adopted in this paper (Gnos 2004; Wray 2004; Pettifor 2006). It could be suggested, however, that Marx implied the possibility of the ex nihilo creation of money from the banking system, in his treatment of bills of exchange (and promissory notes and overdrafts), but it was not made explicit in the text (Marx 1981). Indeed, as Itoh notes (p.87), Marx had instead discussed the significance and role of idle funds in the development of the capitalist commercial credit system, something that is not necessary in the financial system of today (Itoh 1999). Unfortunately, as many have noted, part of the interpretation difficulty that stems from Marx's work on credit, is that it remained unfinished by Marx (even in draft form) when Engels came to complete the work for publication (De Brunhoff 1976; Potts 2005).

\section{CONCLUSION}

This paper has sought to demonstrate that there is no a priori argument against the use of the EMP conception of a credit-money unit, with TSSI models that seek to illustrate the general political economy of Marx. The commodity-money magnitudes utilized in the models (and

\footnotetext{
${ }^{7}$ This is, perhaps, defensible given his general treatment of money hoards, and their release of monies into the circulation of commodities.
} 
MELT) are simply replaced by monetary units of credit-money, which pertain to the production period under investigation, providing that the units have the legal sanction of the state. The particular features of commodity money are recognized, however, as attributes in certain contexts, such as the collapse of the state or severe financial crises. Yet, since WW2, an initial concentration of gold hoards by national banks, as backing for the dollar in its role as global (reserve) currency, has been replaced by an entire fiat and credit money (international) financial system that relies upon the jurisprudence of monetary authorities and systemic practice (Lapavitsas 1991; Helleiner 1994). In the context of bank deposit creditmoney, legally sanctioned as acceptable for the payment of taxes, the EMP can therefore be considered an appropriate explanation of modern money.

Marx himself had theorised on the various functions of money, and the behaviour of different money-forms, exploring them within their specific contexts and in logical order. Once the (commodity) monetary equivalent is established (as a measure of value), the exchange value (medium of circulation) function can operate, and then money can be used as a means of payment and international currency (De Brunhoff 1976; Lapavitsas 1991). In addition, there is a (later) development of a capitalist theory of credit, based on bank discounts of bills of exchange, banknotes and overdrafts (Marx 1981). In the circuit of capital, of course, money (and credit) has a significant decision-making (amongst interdependent entities) role in financing production, and Marx therefore also challenges the notion of monetary neutrality (De Brunhoff 1976). Yet, Marx did not adequately outline the ex nihilo nature of modern credit-money issue, or anticipate the use of bank deposits as money and, the insights from the EMP are therefore a helpful aid to our understanding of money operation. Notwithstanding, Marx did identify the latent (private) banking infrastructure of today, with its evolving forms of capitalist credit, and the LTFRP also provides a convincing explanation of many recent (financial) crises as surplus capital migrates towards fictitious capital in search of profits.

The TSSI, in seeking to restore Marx's political economy, has illuminated the consistency in his method (although not necessarily the empirical validity) and also provides (with the EMP) a more realistic description of the functioning of the modern monetary system and its monetary equivalent unit (currency) for purposes of commodity valuation.

\section{REFERENCES}

Carchedi, G. (1996). Non-Equilbrium Market Prices. Marx and Non-Equilbrium Economics. A. Freeman, Carchedi, G. Cheltenham, Edward Elgar.

Davidson, P. (2002). Financial Markets, Money and the Real World. Cheltenham, Edward Elgar.

De Brunhoff, S. (1976). Marx on Money. New York, Urizen.

Freeman, A. (1996). The Psychopathology of Walrasian Marxism. Marx and NonEquilibrium Economics. A. Freeman, Carchedi, G. Cheltenham, Edward Elgar.

Freeman, A. (2004). Geld (Money). Personal RePEc (MPRA) Archive Paper. Munich.

Gnos, C. (2004). Circuit Theory as an Explanation of the Real World. Modern Theories of Money: The Nature and Role of Money in Capitalist Economies. L.-P. R. S. Rossi. 
Graziani, A. (2003). The Monetary Theory of Production, Cambridge University Press.

Harris, L. (1981). Monetary Theory. Singapore, McGraw-Hill.

Hawtrey, R. G. (1919). Currency and Credit. London, Longmans, Green \& Co.

Helleiner, E. (1994). States and the Re-emergence of Global Finance: From Bretton Woods to the 1990's, Cornell University Press.

Itoh, M. L., Costas (1999). The Political Economy of Money and Finance. Chippenham, Macmillan.

Kliman, A. (2007). Reclaiming Marx's Capital: A Refutation of the Myth of Inconsistency. United States, Lexington.

Knapp, G. F. (1924). The State Theory of Money. London, Macmillan.

Kregel, J. (2008). Using Minsky's Cushions of Safety to Understand the Sub-Prime Mortgage Crisis, Brunei Gallery: School of Oriental and African Studies.

Lapavitsas, C. (1991). "The Theory of Credit Money: A Structural Analysis." Science and Society 55(3): pages 291-322.

Lapavitsas, C. (1994). "The Banking School and the Monetary Thought of Karl Marx." Cambridge Journal of Economics 18: 447-461.

Mandel, E. (1987). Karl Marx. Marxian Economics. M. M. a. P. N. John Eatwell. Hong Kong, Macmillan.

Marshall, A. (1890). Principles of Economics. New York, Macmillan.

Marx, K. (1848). The Communist Manifesto.

Marx, K. (1970). A Contribution to the Critique of Political Economy. Union of Soviet Socialist Republics, Lawrence \& Wishart.

Marx, K. (1971). Theories of Surplus Value: Part Three. Moscow, Progress.

Marx, K. (1976). Capital: Volume One. St Ives, Penguin.

Marx, K. (1978). Capital: Volume Two. Aylesbury, Penguin.

Marx, K. (1981). Capital: Volume Three. Bungay, Penguin.

Mouatt, S. (2008). "Evaluating Stephen Zarlenga's Treatment of Historical Monetary

Thought." International Journal of Social Economics 35(11). 
Naito, A. (2008). Money, Credit and the State: Post Keynesian Theory of Credit Money and Chartalism. Association of Heterodox Economics Annual Conference, Anglia Ruskin University: Cambridge.

Pettifor, A. (2006). The Coming First World Debt Crisis. Chippenham, Palgrave, Macmillan.

Potts, N. (2005). The Political Economy of Money, Profitability and Value. London School of Economics. London, University of London.

Ramos-Martinez, A. (2004). Labour, Money, Labour-Saving Innovation and the Falling Rate of Profit. The New Value Controversy and the Foundations of Economics. A. Freeman, Wells, J, Kliman, A. Cheltenham, Edward Elgar.

Rochon, L.-P. R., Sergio (2007). "Monetary Policy without Reserve Requirements: Central Bank Money as a Means of Final Payment on the Inter-Bank Market." CEMF Conference "Post-Keynesian Principles of Economic Policy" University of Burgundy, Dijon, December.

Tily, G. (2006). "Keynes, the Post-Keynesians and the Curious Case of Endogenous Money."

Walras, L. (1926). Elements of Pure Economics. Paris, Pichon.

Wray, L. R. (2004). When are Interest Rates Exogenous? Working Paper No.30, Jerome Levy Economics Institute.

Zarlenga, S. (2002). The Lost Science of Money - The Mythology of Money: The Story of Power. United States, The American Monetary Institute. 